\title{
Inhibition of nitric oxide synthesis for four days induces vascular abnormalities and myocardial infarct areas but not significant arterial hypertension
}

\author{
Inibição da síntese do óxido nítrico durante quatro dias induz anormalidades vasculares $e$ \\ áreas de infarto miocárdico, porém, não induz hipertensão arterial significativa
}

Ricardo Xavier-Vidal ${ }^{1}$

\begin{abstract}
Background: Nitric oxide is an endothelium vasorelaxing factor and at least in some cases is the main cause of arterial hypertension, which is one of the most important risk factors of cardiovascular diseases. In Brazil, cardiovascular diseases are the first cause of mortality, representing about $30 \%$ of the total deaths. The L-NAME ( $\mathrm{N}^{\omega}$-nitro-arginine-methyl-ester) blocks the nitric oxide synthesis necessary to maintain the normal arterial pressure. Objective: To study lesions in myocardium due to the inhibition of nitric oxide synthesis during four days (via L-NAME oral administration, concentration: 75 mgs versus $100 \mathrm{~mL}^{-1}$ ).

Methods: Fourteen normotensive young adults Wistar rats were submitted, during four days, to L-NAME. Six rats were utilized as the Control Group. At day 4 of the experiment, the animals were anesthetized, weighed, and their thoraxes were opened, and the cardiotomy was performed. The hearts were weighed, fixed, and processed using routine methods, and they were sectioned in $3 \mu \mathrm{m}$ and stained.

Results: Abnormalities were observed in the wall of arterial vessels of any dimension, as vascular damage with increasing wall thickness related mainly to proliferation of arterial smooth muscle cell in submitted animals. Proliferation of cells in the intimal layer and its thickening were also observed in small arterial vessels (arteriole). Infarct areas were present.

Conclusions: The present data suggested that inhibition of nitric oxide synthesis for four days induces vascular abnormalities and myocardial infarct areas, but not arterial hypertension.
\end{abstract}

Keywords: nitric oxide; L-NAME; hypertension; cardiopathy; heart.

\section{Resumo}

Contexto: O óxido nítrico é um fator de relaxamento vascular e, pelo menos em certos casos, é a principal causa de hipertensão arterial no ser humano. A hipertensão arterial é um importante fator de risco de doenças cardiovasculares. No Brasil, as doenças cardiovasculares são a primeira causa de mortalidade, representando cerca de $30 \%$ do total de óbitos. O L-NAME ( ${ }^{\omega}$-nitro-arginina-metil-éster, Sigma Chemical, St. Louis) bloqueia a síntese do óxido nítrico necessária para a manutenção da pressão arterial normal.

Objetivo: Estudar as lesões miocárdicas ocorridas por razão da inibição da síntese do óxido nítrico durante quatro dias (por meio da administração oral de L-NAME em concentração de 75 mgs versus $100 \mathrm{~mL}^{-1}$ ).

Métodos: Quatorze ratos Wistar jovens normotensos adultos foram submetidos durante quatro dias ao L-NAME. Seis foram utilizados como Grupo Controle. Aos quatro dias de experimento, os animais foram anestesiados, pesados, os tórax foram abertos e a cardiomiotomia foi efetuada. Os corações foram pesados, fixados e processados usando métodos de rotina e cortados em $3 \mu \mathrm{m}$ de espessura e corados.

Resultados: As anormalidades foram observadas nas paredes arteriais de vasos de todos os calibres, como, por exemplo, o aumento da parede arterial relacionada principalmente à proliferação das células musculares lisas dos animais submetidos ao bloqueio do óxido nítrico. Também foi identificada proliferação das células da túnica íntima e seu espessamento nos vasos arteriais de pequeno calibre (arteríolas). Áreas de infarto estavam presentes. Conclusões: Os resultados sugerem que a inibição do óxido nítrico durante quatro dias induz anormalidades vasculares e áreas de infarto do miocárdio, contudo, não induz hipertensão arterial.

Palavras-chave: óxido nítrico; L-NAME; hipertensão; cardiopatia; coração.

Study carried out at the Associação Xavier-Vidal para Direitos Humanos, Ciência, Tecnologia e Desenvolvimento and at Universidade Federal do Rio de Janeiro (UFRJ) - Rio de Janeiro (RJ), Brazil. ${ }^{1}$ Doutor em Ciências Morfológicas pelo Instituto de Ciências Biomédicas da Universidade Federal do Rio de Janeiro - UFRJ; Presidente e Pesquisador da Associação Xavier-Vidal para Direitos Humanos, Ciência, Tecnologia e Desenvolvimento - Niterói (RJ), Brazil.

Financial support: CAPES, CNPq, IPPMG/UFRJ, CIC-HUCFF/UFRI and AXV.

Conflict of interest: nothing to declare.

Submitted on: 22.08.11. Accepted on: 11.01.12

J Vasc Bras. 2012;11(2):132-136. 


\section{Introduction}

Nitric oxide (NO) is a vascular smooth muscle relaxation factor. The L-NAME, ${ }^{\omega}$-nitro-arginine-methyl-ester, is an analog and antagonist of L-arginine (Substract of NO Synthase, NOS) and its oral or parentheral administration interrupt the NO synthesis, which is necessary for the maintenance of normal arterial pressure that causes arterial hypertension, a significant experimental cardiac hypertrophy, and lesions on myocardial mass ${ }^{1-9}$. Nowadays, it has been discussed the degree of direct influence of $\mathrm{NO}$ - and the influence of hypertension produced by NO blockage in hypertrophy and cardiac lesions in the L-NAME model. Since the reduction of arterial hypertension in this model does not reduce significantly the hypertrophy and the lesions, these morbid processes are probably related to $\mathrm{NO}$ deficit $^{6}$. Some studies showed that at least in some cases of hypertension, NO synthesis is reduced ${ }^{10-12}$. Nevertheless, some authors disagree ${ }^{13-14}$, suggesting that these differences in results may be related to population differences. Ribeiro et al. ${ }^{15}$ suggested that the renin-angiotensin-aldosterone system was possibly involved in the L-NAME model. Felix et. al. ${ }^{16}$, using infusion doses of aldosterone and angiotensin II in rats, found results of reactive and reparative fibrosis similar to our previous published results.

\section{Objective}

The aim of this paper is to study the myocardium submitted to chronic inhibition of systemic NO synthesis during four days.

\section{Methods}

A total of 14 normotensive young adult Wistar rats from several breeds was used. Arterial pressure for each experimental group was obtained using the hydraulic pletismography method ${ }^{17}$. The initial pressure of all animals, before the experiment, was normal and not above $119 \mathrm{mmHg}$. After the evaluation of the arterial pressure, each rat was placed in an individual plastic box. To perform NO blockage, we utilized L-NAME (Sigma Chemical, St. Louis) via oral administration at concentration of $75 \mathrm{mg} / 100 \mathrm{~mL}$ in drinking water (about 60 milligrams per kilograms of body weight $)^{5-9,18-22}$. We submitted eight rats during four days to L-NAME (Group L) and six were utilized as a Control Group (Group C). At day 4 of experiment, rats were anesthetized with ethylic esther, and a complete necropsy was performed. The hearts were fixed in $4 \%$ buffered formaldehyde and processed using routine methods sectioned in $5 \mu \mathrm{m}$ and stained in hematoxilin-eosin and Masson's trichrome.

\section{Results}

The arterial pressures were normal, both in control and in L-NAME animals, not superior of $120 \mathrm{mmHg}$ (Table 1). All control animals (Group C) presented normal pattern of myocardial tissue. Veins were mainly restricted to an endothelial layer with a scarce intima configuring a sinusoidal aspect. These veins were mainly seen in $1 / 3$ external layer, while arteries were mainly seen in the middle $1 / 3$ of the myocardium tissue. The inner of myocardial wall (subendocardial) had mainly veins and Tebesian vessels. Thickness of adventitia was almost inferior to the thickness of media. In Group L, abnormalities were observed in the wall of arterial vessels of any dimension, as vascular damage with increasing wall thickness related mainly to proliferation of the arterial smooth muscle cell. Proliferation of cells in the intimal layer and its thickening were also observed in small arterial vessels (arteriole). We also observed reactive fibrosis (including perivascular) between myocardial and vascular wall muscle cells. Large areas of perivascular fibrosis were seen. Hypertrophic process of arterial smooth muscle cell contributing to the thickening of arterial wall is also possible to occur. In this period, infarct areas were present. Abnormalities both occured in arterial and vein vessels of all dimensions. Our main contribution in this article is that animals submitted to chronic inhibition of systemic NO synthesis at day 4 presented vascular abnormalities and myocardial infarct areas, but they did not present significant arterial hypertension (Figure 1).

Table 1. Tail-cuff arterial pressure $(\mathrm{mmHg})$ measured using hydraulic pletismography (mean/standard error).

\begin{tabular}{llll}
\hline & Control $(n=6)$ & $L(n=8)$ & p-value \\
\hline Group 1 & $106(M X=115) / 3.6$ & $107(M X=114) / 2.3$ & $>0.05$ \\
Initial AP & $109(M X=116) / 2.7$ & $110(M X=120) / 2.7$ & $>0.05$ \\
Final AP & \\
\hline $\begin{array}{l}\text { AP - arterial pressure; } L \text { - submitted to L-NAME; p-value - test of similarity evaluating the } \\
\text { probability of arterial pressure of Control Group compared to group submitted to L-NAME } \\
\text { be equal to zero; } M X \text { - maximum value. }\end{array}$
\end{tabular}




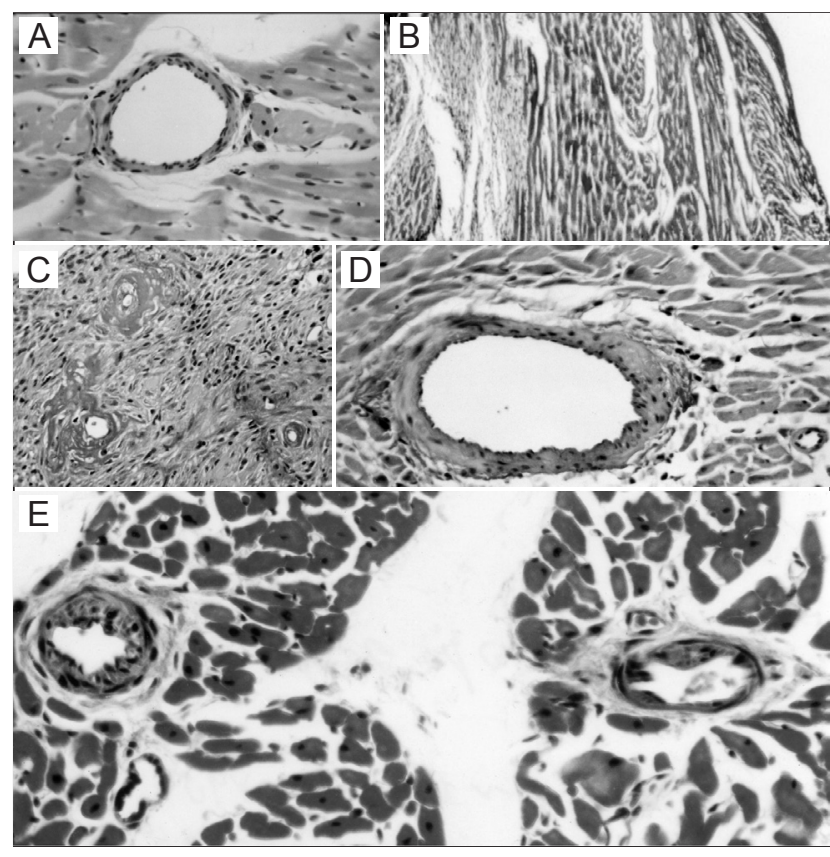

Figure 1. A: Control (Group C) presents myocardium and all vessels with a normal pattern (hematoxilin-eosin, $400 \mathrm{X}$ ). B: myocardium of submitted group (Group L) with large infracted areas (Masson's trichrome, $100 \mathrm{X}$ ). C, D and E: myocardium abnormalities of submitted group (Group L) (Masson's trichrome, 400 X). During the four days, rats were normotensive but nitric oxide systemic blockage was present.

\section{Discussion}

Recently, the degree of direct influence of NO in cardiac morbid process is yet disputable.

Previous papers discussed results found in animals submitted to L-NAME during days 21 and 35, 5,7,918-20,22 and also day $43^{8,19,21}$. Moreno Jr. et al. ${ }^{3-4}$ worked with animals submitted during days 2 and $3^{4}$ and day $56^{1,3}$, they discussed data from days 28,42 and 56 of submission. Moreno et al. ${ }^{4}$ evaluated the arterial pressure at 24 (day 1 ) and 48 hours (day 2) without significant differences, comparing Experimental with Control Groups. In the present paper, we have tested the arterial pressure at 96 hours (day 4) and we did not find significative differences in arterial pressure comparing Control with Experimental Group; besides, we found myocardial abnormalities and lesions.

Concerning the main genes code for NO-generating enzymes in the problem of hypertension in the mammalian genome, three genes encoding three different NO synthases (eNOS, nNOS, iNOS) generate NO from L-arginine in several cells and under various stimuli. Nevertheless, the inducible NOS (iNOS) is not a candidate gene in causing hypertension. Neuronal NOS (nNOS) is an interesting candidate, since it is expressed in macula densa of kidney and is probably involved in renin regulation. However, endothelial NOS (eNOS) is a strong candidate ${ }^{23}$. Therefore, it is probable the contribution of both nNOS and eNOS in hypertension, even if the eNOS is the main candidate. Mice submitted to eNOS knockout present an arterial pressure level rising about $15^{23}$ or $47 \mathrm{mmHg}^{24}$, comparing with control animals. Also, the basal arterial pressure reduces about $20 \mathrm{mmHg}$ in mice with eNOS overexpression ${ }^{23}$. NO blockage has been suggested as promoting fibrosis ${ }^{5-6,8,18-19,25}$. Hocher ${ }^{26}$, working with renovascular hypertension (Goldblatt's method, left renal artery), found abnormalities in media/lumen ratio in intramyocardial vessels. In the present work, using NO systemic blockage (L-NAME Model), we identified increase of vascular media, fibrotic scars, and perivascular fibrosis in left, right, and septal myocardium, similar to those lesions found by Hocher $^{26}$ in renovascular hypertension. Felix et al. ${ }^{16}$, using infusion dose of aldosterone and angiotensin II in rats, found reactive and reparative fibrosis similar to those found in previous $\mathrm{s}^{5-9,18,19,22}$ and present works.

Lesions on cardiac tissue occurred in L-NAME model not mainly because of the hypertensive process, since in NO blockage/nonhypertensive rats we had the same lesions (nevertheless in less intensity) to those occurred in NO blockade hypertensive rats ${ }^{1,3,4,6,18}$. Moreno Jr. et al. ${ }^{3,4}$, using L-NAME plus enalapril, found that enalapril avoided arterial hypertension and left ventricular hypertrophy, but did not avoid myocardial lesions. Numaguchi et al. ${ }^{1}$ found that concomitant submission to L-NAME and hydralazine did not avoid necrotic and reparative fibrotic areas in myocardium at day 56 (eight weeks). Our previous ${ }^{6,18}$ and present results also confirm these data.

Our present results related to myocardial abnormalities and lesions at day 4 of submission without hypertension support the idea that hypertrophy and myocardial abnormalities in hypertension - and other morbid cardiac processes -, at least in some cases in humans, occurred because of the NO organic deficit and not because hypertension. These results are also similar to abnormalities and lesions in which arteriosclerosis occur ${ }^{27}$. A previous work developed a qualitative chronopathological study concerning abnormalities in myocardium, due to NO blockage. Authors submitted Wistar rats to L-NAME (Group L) via oral administration dissolved in water $(750 \mathrm{mg} / \mathrm{L})$. Other Wistar rats were submitted concomitantly to L-NAME and hydralazine hydrocloride $(120 \mathrm{mg} / \mathrm{L})(\mathrm{L}+\mathrm{H} \text { Group })^{6}$. At days 4 and 14 (Group L), myocardial abnormalities and lesions were found, while in $\mathrm{L}+\mathrm{H}$ Group we could not 
identify abnormalities. Considering Group L at day 28, the myocardium presented characteristic fibrosis (reactive and reparative post infarct areas), vascular damage with increasing wall thickness due mainly to proliferation of the arterial smooth muscle cell. Total obliteration of vessels was noted only in this period. It was also observed reactive fibrosis between muscle cells of the vascular wall and proliferation of cells in the intimal layer. In $\mathrm{L}+\mathrm{H}$ Group (day 28), it was also observed similar vascular abnormalities described for the Group L (less frequent and apparent). In $\mathrm{L}+\mathrm{H}$ Group, total vascular obstructions were not identified. In L+H Group, infarct areas were not observed. Control Groups did not present any abnormalities. These results support the idea that, at least in some cases, hypertrophy, vascular abnormalities and myocardial lesions in arterial hypertension can occur because of the reduction in organic NO production. These results also suggested that such morbid processes can be postponed by the use of hydralazine, which, however, does not avoid abnormalities after long-term experimental NO blockage ${ }^{6,18}$. Some cardiac morbid processes in human newborns may be also related to NO deficit as we suggested before ${ }^{28}$.

Concerning multivariate allometry, some contributions on the study of the L-NAME model using multivariate allometry evaluated cardiac lesions occurring in rats submitted to NO blockage at days $21^{7,18}$ and $35^{9,18}$. Results of day 21 suggested that the nuclei of the myocytes have the major variance between the variables utilized. Therefore, it can clearly identify the growth center advocated by Huxley as the myocyte nuclei. In conclusion, the data show that under this experimental hypertension myocytes undergo intense nuclear changes probably involving great metabolic activities. In other words, these data also suggested that to researchers interested in L-NAME models at $21^{\text {st }}$ day of submission, it is important to emphasize cardiomyocyte nuclei and occurrences linked to them $^{7,18}$. Results of day 35 suggested that even if other myocardial stereological parameters vary significantly, the probable most intense variations during hypertrophy and lesions in this model at day 35 are concerning vascular changes with emphasis on vascular length $(\mathrm{Lv})^{9,18}$.

\section{Conclusions}

The present results related to myocardial abnormalities and lesions at day 4 of submission without hypertension support the idea that hypertrophy and myocardial abnormalities in hypertension - and other morbid cardiac processes -, at least in some cases in humans, occurred because of the NO organic deficit and not because of the hypertension.

\section{Acknowledgments}

The author thanks the unique and Eternal God and His Son Jesus Christ and His absolutely Holy Spirit. The main author had a $\mathrm{PhD}$ fellowship from Coordenação de Aperfeiçoamento de Pessoal de Nível Superior (CAPES), Brasília, Brazil. This article was supported by CAPES, National Counsel of Technological and Scientific Development - CNPq, IPPMG/UFRJ, CIC-HUCFF/UFRJ and AXV. The author thanks the families Xavier and Vidal, especially, José Vandir Jorge Vidal (in memoriam) and Marina Xavier Vidal. The author thanks the Professors Waldemar Silva Costa, Kalil Madi, Aline de Abreu Reis, Leandra da Silva Reis, Ana Carolina de Azevedo Carvalho, Fernanda Oliveira Laranjeira, Simone Marques Fernandes, Marcelo Guimarães, Marcelo Aranha Gardel, Sonia Oliveira Souza and Nádia Maria S. Marques for their suggestions. To Maria Erlânia da Silva Oliveira for her support.

\section{References}

1. Numaguchi K, Egashira K, Takemoto M, et al. Chronic inhibition of nitric oxide synthesis causes coronary microvascular remodeling in rats. Hypertension. 1995;26(1):957-62.

2. Ignarro L.J. Role of nitric oxide in the pathophysiology of hypertension; physiology and pathophysiology of nitric oxide. Kidney Intern. 1996;49(Suppl 55):S2-5.

3. Moreno Jr.H, Nathan LP, Costa SKP. Enalapril does not prevent the myocardial ischemia caused by the chronic inhibition of nitric oxide. Eur J Pharmacol. 1995;287:93-6.

4. Moreno Jr.H, Nathan LP, Metze K, et al. Non-specific inhibitors of nitric oxide synthase cause myocardial necrosis in the rat. Clin Exper Pharmacol Physiol. 1997;24:349-52.

5. Xavier-Vidal R, Madi K, Lima RJ, Nádia MS, Reis AA, Paes LS. Estudo anatomo-patológico experimental em miocárdio de animais submetidos à hipertensão arterial via bloqueador da síntese do óxido nítrico. Rev Port Cardiol. 1999;18(4):381-91.

6. Xavier-Vidal R, Madi K, Reis AA, et al. Hydralazine reduces myocardial tissue damage in rats submitted to chronic inhibition of systemic nitric oxide synthesis during days 4, 14 and 28. J Bras Patol Med Lab. 2003;39(3):245-52.

7. Xavier-Vidal R, Carvajal SSR, Cunha SB, Madi K. Multivariate Allometry and myocardium abnormalities during experimental systemic nitric oxide blockage. J Brasil Patol Med Lab. 2004;40(3):203-8.

8. Xavier-Vidal R. Anatomic-pathological study of the myocardium submitted to chronic Inhibition of the systemic synthesis of Nitric Oxide (NO) on the structure of the heart. CLINICS. 2005;60(2):85-92.

9. Xavier-Vidal R, Carvajal SSR, Cunha SB, Madi K. Multivariate allometry using stereological data belongs from I-name model induces hypertension, cardiac hypertrophy and stereological myocardium lesions (day 35). Braz I Investig Pathol Morphol Morphom. 2006;1(1):7-14.

10. Panza JA, Garcia CE, Kilcoyne CM, Quyyumi AA, Cannon RO. Cannon. Impaired endothelium-dependent vasodilatation in 
patients with essential hypertension: evidence that nitric oxide abnormality is not localized to a single signal transduction pathway. Circulation. 1995;91(6):1732-8.

11. Brush JE, Faxon DP, Salmon S, Jacobs AK, Ryan TJ. Abnormal endothelium-dependent vasodilatation in patients with essential hypertension. J Am Coll Cardiol. 1992;19:809-15.

12. França MF. Efeitos da L-arginina por via endovenosa sobre a pressão arterial sistema renina-angiotensina, hemodinâmica renal e excreção de sódio em hipertensos essenciais. Rio de Janeiro: State University of Rio de Janeiro (M.Sc. Theses); 1995.

13. Cockcroft JR, Chowienczk PJ, Benjamin N, Ritter TJ. Abnormal endothelium-dependent vasodilatation in patients with essential hypertension. N Engl J Med. 1994;330:1036-40.

14. Hayakawa $H$, Raij $L$. The link among nitric oxide synthase activity, endothelial function, and aortic and ventricular hypertrophy in hypertension. Hypertension. 1997;29(2):235-41.

15. Ribeiro MO, Antunes E, De Nucci G, Lovisolo SM, Zatz R. Chronic inhibition of nitric oxide synthesis. A new model of arterial hypertension. Hypertension. 1992;20:298-303.

16. Felix J, Ramires A, Sun Y, Weber KT. Myocardial fibrosis associated with aldosterone or angiotensin II administration: attenuation by calcium channel blockage. J Mol Cell Cardiol. 1998;30:475-83.

17. Xavier-Vidal R, Madi K, Menezes FG. Hydraulic Pletismography: detailed confection of a low cost tail-cuff equipment used to measure arterial pressure in conscious small mammals. Braz I Investig Pathol Morphol Morphom. 2006;1(1):33-44.

18. Xavier-Vidal R. Avaliação morfológica, à microscopia óptica convencional, do miocárdio ventricular de ratos Wistar submetidos ao bloqueio sistêmico da síntese do óxido nítrico. [dissertation]. Rio de Janeiro, RJ: Universidade Federal do Rio de Janeiro; 2000.

19. Xavier-Vidal R. Alterações morfológicas do miocárdio devidas a hipertensão arterial induzida por inibidor da síntese do óxido nítrico. Estudo experimental em ratos. [thesis]. Rio de Janeiro, Federal Fluminense University, Antônio Pedro Universitary Hospital, Department of Patologia; 1995.

20. Xavier-Vidal R, Madi K. A hipertensão arterial e a hipertrofia cardíaca com ênfase ao uso experimental de bloqueadores da síntese do óxido nítrico: uma breve revisão. UNIMAR. 1997;19(2):593-610.
21. Xavier-Vidal R. Hipertrofia cardíaca durante a inibição sistêmica experimental da síntese do óxido nítrico. Rev Cient C Univ Barra Mansa. 2002;3(6):54-63.

22. Xavier-Vidal R. O Método Estereológico dirigido aos estudos Biológicos e Biomédicos; Teoria e Prática com uso do Modelo Experimental L-NAME de bloqueio sistêmico da síntese do óxido nítrico. Braz J Investig Pathol Morphol Morphom. 2006;1(3):31-53.

23. Soubrier F. Nitric oxide synthase genes; candidate genes among many others. Hypertension. 1999;33:924-6.

24. Stauss HM, Mafz R, Mrowka R, Persson PB. Blood pressure control in eNOS knock-out mice: comparison with other species under NO blockade. Acta Physiol Scand. 2000;168:155-60.

25. Kolpakov V, Gordon D, Thomas JK. Nitric oxide-generating compounds inhibit total protein and collagen synthesis in cultured vascular smooth muscle cells. Circ Res. 1995;76(2):305-9.

26. Hocher B. Endothelin sustem-dependent cardiac remodeling in renovascular hypertension. Hypertension. 1999;33:816-22.

27. Contran RS, Kumar V, Robbins SL. Robbins. Pathologic basis of disease. $5^{\text {th }}$ edition. Philadelphia, W.B.: Saunders Company; 1999.

28. Xavier-Vidal R, Madi K. Comparação entre os miocárdios ventriculares direito e esquerdo durante o período fetal humano. Avaliação Estereológica. Arq Bras Cardiol. 1999;72(5):587-92.

Correspondence Ricardo Xavier-Vidal Associação Xavier-Vidal para Direitos Humanos, Ciência, Tecnologia e Desenvolvimento Alameda São Boaventura, 348 - Fonseca CEP 24120-196 - Niterói (RJ), Brazil E-mail: ricardoxv@globo.com

Author's contribution Conception and design: RXV Analysis and interpretation: RXV

Data collection: RXV

Writing the article: RXV Critical revision of the article: RXV Final approval of the article*: RXV Statistical analysis: $R X V$

Overall responsibility: RXV *The author has read and approved the final version submitted to J Vasc Bras. 